\title{
Fear of fluoride
}

\author{
D. Reekie ${ }^{1}$
}

\begin{tabular}{|c|c|c|c|}
\hline $\begin{array}{l}\text { Examines a common problem } \\
\text { encountered by GDPs in everyday } \\
\text { practice }\end{array}$ & $\begin{array}{l}\text { Provides a new historical perspective of } \\
\text { the fluoride and amalgam scares. }\end{array}$ & $\begin{array}{l}\text { Offers an illuminating analysis of the } \\
\text { 'scare' phenomenon }\end{array}$ & $\begin{array}{l}\text { Helps other GDPs understand the scare } \\
\text { problem and how to counter it in the } \\
\text { future. }\end{array}$ \\
\hline
\end{tabular}

Discusses how dental and medical scares have resulted in a "culture of fear" which has damaged patients and dentists. Forty years of pessimism have created a demoralised and risk-averse society. The reality of a steadily improving world demands a new attitude of rational optimism and a healthy scepticism about new scares.

\section{The F word}

Six months ago, 10-year-old Sophie, a confident, lively child from a well-educated and prosperous family walked cheerfully into my surgery. ' $H i$ ' she said with a grin, in response to my greeting and sat down in the chair for her yearly dental examination. She was a regular attender who had been coming for check-ups ever since she was a tot. It was a shock to discover a large carious cavity in her lower second primary molar. We were all shocked, Sophie, me and her Dad. What on earth could have gone wrong in such a low-risk patient? The usual investigations followed. No, Sophie was not especially fond of sweets. The family were very health conscious and ate an excellent diet. The children were scrupulous teeth brushers which they did twice a day. At last the ' $\mathrm{F}$ ' word was mentioned. What sort of toothpaste did they use and did it contain fluoride? Actually, the Father admitted, they had changed to an herbal, fluoride-free paste about six months ago. He 'did not believe in fluoride' and was worried about possible health risks which he had heard about on the Internet.

Sophie is not alone. Like every dentist, I have a number of patients like Sophie's Dad who fear fluoride, X-rays and 'chemicals'. I have one lovely lady who is a medical consultant.

${ }^{1}$ General Dental Practitioner, Appletree Dental Studio, 33 Herne St, Herne Bay, CT6 7HL

Correspondence to: D. Reekie

Email: dareekie@aol.com

Refereed Paper. Accepted 15 November 2016

DOI: 10.1038/sj.bdj.2017.23

${ }^{\circ}$ British Dental Journal 2017; 222: 16-18
She readily admits to a phobia of chemicals and would rather have a tooth extracted than a composite or amalgam filling. She is an extreme example, but I am sure every general dental practitioner (GDP) in the country has patients with similar fears.

Dentistry has been subject to a succession of panics and scares over the last few decades. Fluoride was the first and perhaps the most damaging one. It seems to have originated as a reaction to the well-meaning attempts by the profession to get widespread water fluoridation accepted as a public health measure to reduce the then epidemic incidence of caries. I have to admit to some sympathy for the argument that this is a violation of the right of people not to be subjected to compulsory medication. Despite this, there is now overwhelming evidence that fluoride is safe and highly effective and its concrete health benefits outweigh the rather abstract ethical argument. In the 1970s the opposition to fluoride exploded. You only have to look at some of the anti-fluoridationists' posters and adverts to see just how extreme the opposition was. Even scientists got in on the act. When the two researchers, Yiamouyiannis and Burk, ${ }^{1}$ published their study (1977) supposedly establishing a link between fluoride and cancer, the scare went viral and was, it seems, lodged forever in the public's subconscious. No amount of academic rebuttal and comprehensive demolition of the junk science of Yiamouyiannis and Burk could ever eradicate it. It remains alive and well to this day, lurking in people's brains like a herpes simplex virus in a ganglion, emerging every now and again on the Internet to spread its damaging message into new minds.

\section{Amalgam armageddon}

If the 1970s was the heyday of the fluoride scare, the 1980s was the decade of the great dental amalgam panic. The toxic time bomb, ${ }^{2}$ published in 1984, immediately became a best seller. It claimed that the mercury in dental amalgam was the cause of a wide variety of symptoms including headaches, nausea, brain damage, kidney disease, muscle weakness and digestive disorders. Dentists were besieged by patients asking to have all their amalgams removed and replaced with composite. Again no amount of reputable scientific studies was enough to kill this mind virus off and like fluoride it remains lodged in millions of brains and across the Internet. A family member called me not so long ago to ask if it was safe to have amalgams in their mouth. I have every sympathy with unfortunate sufferers of conditions like MS and ME who are desperate for a solution to their conventionally untreatable disease and who grasp at the possibility that amalgam removal may help. The fact that this is a damaging and expensive delusion is the sad truth.

\section{The mad gay cow plague}

In the early 1980 s a terrifying new disease was identified, which came to be called AIDS, and was caused by the human immune deficiency virus (HIV). When a cluster of new cases was discovered among the patients of the Florida dentist David Acer it created a furore. Suddenly dentistry came under suspicion of spreading the deadly infection. Patients around the world became increasingly 
reluctant to have dental treatment and dentists were forced to adopt a stringent set of cross-infection control measures. The fact that the Acer cluster was not repeated and remains to this day something of a mystery did not diminish the scare. HIV positive dentists were prevented from practising and there were regular panics when dentists had been found to be lax in their infection control, leading to headlines with the general form of: ' $\mathrm{X}$ patients at risk of AIDS in dirty dentist scare. These continue to the present day. This is not to belittle the real and serious nature of the threat and a perhaps understandable overreaction of the authorities. With the benefit of hindsight an over-reaction was indeed what happened, which blighted the careers and the pockets of many dentists.

If the AIDS scare was bad enough it was nothing to what happened when another new disease was identified. BSE (bovine spongiform encephalitis) or mad cow disease had been around for a decade or so. A new form of the disease -CJD (Creutzfeldt-Jakob disease) - had been identified and in 1996 the health minister announced to a shocked House of Commons that this may have been transmitted to humans through the eating of BSE infected beef. All hell was let loose and the press had a field day accusing the government of a cover up. Forecasts of millions of CJD victims were bandied about.

Laughable in retrospect, but not at the time. The CJD infectious agent was identified as a prion protein and, yet again, dentists paid a high price in terms of terrified patients, stringent increases in infection control (HTM 01-05) and a massive burden of new regulation by being placed under the supervision of the Care Quality Commission.

\section{The age of doom}

The fluoride, amalgam, AIDS and CJD panics were not isolated incidents. The period between 1960 and 2010 was in fact a veritable 'age of doom' with a myriad of scares, panics and predictions of catastrophe (Table 1). The apocalypse was around every corner.

It's amazing that we survived at all! But we did. Astonishingly, not a single one of the doomsters predictions has yet turned out be remotely as devastating as claimed. Of course not every scare will be false. The truth will only emerge after years or decades and they must mostly be taken seriously. The track record of the phenomenon is clear: most scares turn out to be either false or exaggerated. Maybe the granddaddy of them all, climate change, will prove to be the exception. Maybe not.

The sociologist, Professor Frank Furedi of the University of Kent calls it 'The Culture of Fear.' ${ }^{3}$ A condition in which all risk is seen as unacceptable and belief in humankind's ability to control its environment is lost. Our scientific, industrial civilisation is believed to create more problems than it solves, has overstepped its proper bounds and must suffer from the retribution of nature, in the form of epidemics and social and environmental disaster.

\section{The anatomy of a scare}

Bad things happen. Medical disasters include thalidomide, and haemophiliacs given HIV infected factor VIII. Asbestosis and poisoning with pesticide-containing nerve agents warn us not to be complacent. It is important to be able to tell the difference between a scare and a timely warning, but often this is not possible for years or decades.

Scares share a common pattern to a greater or lesser extent. The following list may help us to distinguish between a true scare and a timely warning:

- They start with a real problem or risk which may be credible to a varying degree.
For example, the risk of nuclear war in the 1960s was highly credible. The risk from fluoride less so

- The risk must be insidious, invisible, universal and existential. An unseen and terrifying menace which could kill us all

- The risk factor must be novel

- The risk is identified or adopted by an individual or small group who become passionate true believers and take an extreme position thereby exaggerating the actual risk

- The true believers act as 'pushers' for the scare and are opposed by 'blockers' who are usually the authorities or established experts. ${ }^{4}$ For example, anti-fluoridationists versus dentists

- The pushers gain advantage by using a credulous media who are always interested in dramatic bad news and by engaging maverick scientists who lend credibility to the cause

- The pushers discredit the blockers with accusations of protecting vested interests and cover ups

- The blockers either hold the line or are finally overwhelmed by the pressure of public opinion and embrace the cause or agree to concessions

- When the blockers hold firm the pushers go underground and wage guerrilla war from anti-establishment media or the Internet.

\begin{tabular}{l|l|l}
\hline \multirow{2}{*}{ Table $\mathbf{1}$ List of scares } & Health & Social and moral \\
\hline DDT & Salmonella & Overpopulation \\
\hline Nuclear accident & Listeria & Nuclear war \\
\hline Global cooling & MMR & Violence \\
\hline Chemical pollution & SARS & Drugs \\
\hline Acid rain & Bird flu & Paedophilia \\
\hline Ozone hole & Swine flu & Child abuse \\
\hline Global warming & Ebola & Satanic abuse \\
\hline Extreme weather & MRSA & Crime \\
\hline Millennium bug & E. coli & Economic collapse \\
\hline Peak oil & Obesity & Energy crisis \\
\hline Water shortage & HIV & Globalisation \\
\hline Resource depletion & Antibiotic resistance & Famine \\
\hline Mass extinction & Fluoride & Sexual freedom \\
\hline Deforestation & Amalgam & War \\
\hline GM crops & Saturated fat & Family breakdown \\
\hline & &
\end{tabular}




\section{The great paradox}

The amazing thing is that during the decades of the 'Age of Doom', the world, far from collapsing into chaos and disaster, was steadily getting better. Yes, it's hard to believe I know. A survey in 2013 showed that over $71 \%$ of the population were convinced that the world was getting worse and only $5 \%$ believed it was getting better. ${ }^{5}$ The hard facts contradict this pessimism. It is astonishingly true that almost every single measurable indicator of human welfare has improved. If you don't believe me just check the statistics. A good place to start is the United Nations WHO (World Health Organisation) ${ }^{6}$ and FAO (Food and Agriculture Organisation $)^{7}$ websites which give the best and most authoritative overview of the state of humankind. Even better is to Google Hans Rosling's Gapminder Institute. ${ }^{8}$ $\mathrm{He}$ is a Swedish medical doctor and development expert with a wonderful gift for the visual presentation of data. Information on the decline of violence and crime can be found in Stephen Pinker's book The better angels of our nature ${ }^{9}$ and on the reduction of wars on the Peace Research Institute Oslo, Conflict Data website. ${ }^{10}$

So what has improved? It's a gloriously long list:

- Life expectancy

- Length of healthy life

- Nutrition

- Agricultural production

- Clean water

- Violence

- War

- Nuclear threat

- Pollution

- Crime

- Natural resources

- Oil reserves
- Infant mortality

- Maternal mortality

- Rate of population increase

- Literacy

- LGBT equality

- Gender equality

- Racial equality

- Immunisation

- Climate-related deaths

- Inflation

- Wealth

- Income of the poorest

- Extreme poverty

- Malaria

- TB

- HIV

- Dental health (in developed countries)

- Famine

- Road accidents (in developed countries)

\section{Immunity}

If we accept that scares and panics are damaging and at best wild exaggerations of real threats and at worse completely false, how then do we counter them? The 'age of doom' seemed to reach a peak in the 1990s and has been in slow decline since then, but it is inevitable that more scares will emerge, some of which will affect dentistry. To pursue the metaphor of the scare as a mind virus or 'meme' as Richard Dawkins would call it, ${ }^{11}$ I believe the only effective strategy is to develop a herd immunity. As we have seen, academic rebuttals and scientific evidence, although essential, have limited effect. What is needed is for there to be a general awareness of the scare as a specific phenomenon and the fact that the overwhelming majority of them have turned out to be simply false. Far too often when the scare fails to deliver disaster we simply forget it and move on to the next one. Who now remembers the 'millennium bug' which caused a near panic in 1999 or the 'global cooling' scare of the 1970s? There needs to be a far greater willingness to hold the scaremongers to account and to remind the public of previous false alarms. In this way we can build up a general scepticism which will act as a counter to the tendency we all have to believe the worst.

Mindless optimism is as bad as mindless pessimism. What we need is a balanced realism. The undeniable fact that the world is improving despite the ingrained pessimism created by the 'age of doom' demands a new attitude, a 'rational optimism' as described by science writer Matt Ridley. ${ }^{12}$

I hope that the 'age of doom' is nearly over and that we can regain confidence in our civilisation and in humanity's ability to continue to find creative solutions to the real problems which still exist. The present is good; not good enough, but getting better. The future is bright.

1. Yiamouyiannis J, Burk D. Fluoridation and cancer. Mortality related to artificial fluoridation. Fluoride 1977; 10: 102-123.

2. Ziff S. The Toxic Time Bomb. Aurora Press: New Mexico, 1984.

3. Furedi F. The Culture of Fear. Cassell: London, 1997

4. Booker C, North R. Scared to Death. Bloomsbury: London, 2007.

5. Etchells P. Declinism: is the world actually getting worse? The Guardian (London) 2015 January 16.

6. World Health Organisation. Health data and statistics. Available online at www.who.int/healthinfo/statistics/ en/ (accessed December 2016).

7. Food and Agriculture Organization of the United Nations. Statistics. Available online at www.fao.org/ statistics/en/ (accessed December 2016).

8. Gapminder. Website. Available online at www.gapminder.org/ (accessed December 2016).

9. Pinker S. The Better Angels of our Nature. Viking: New York, 2011.

10. PRIO. Website. Available online at www. prio.org/ (accessed December 2016).

11. Dawkings R. The Selfish Gene. Oxford University Press: Oxford, 1976.

12. Ridley M. The Rational Optimist. Fourth Estate: London, 2010. 